\title{
Study on the Application of Floating Beds of Macrophites (Vetiveria zizanioides and Phragmites australis), in Pilot Scale, for the Removal of Heavy Metals from Água Forte Stream (Alentejo-Portugal)
}

\author{
Teresa Borralho ${ }^{1 *}$, David Gago' ${ }^{1}$ Adelaide Almeida ${ }^{1}$ \\ 1 Department of Technologies and Applied Sciences, Polytechnic Institute of Beja, Beja, Portugal \\ * Corresponding author's e-mail: mtcarvalhos@ipbeja.pt
}

\begin{abstract}
The surrounding area of the Roxo stream sub-basin (basin of the Sado River, Portugal) has completely sterile sections, jeopardizing the productivity of the agricultural activities practiced there. This may be due to the inflow of the Água Forte stream, which has characteristics of Acid Mining Drainage (AMD). The objective of this study was to test the efficiency of heavy metal removal from the Água Forte stream using the macrophyte floating bed technology (Vetiveria zizanioides and Phragmites australis) in a pilot plant, monitoring and evaluating the water quality and performance of macrophytes. Two experiments were carried out in 2019 over 6 months (January to June). Both experiments were performed in polyvinyl chloride (PVC) tanks with the nominal capacity of $1 \mathrm{~m}^{3}$ each. The tanks were filled with about $0.8 \mathrm{~m}^{3}$ of water coming from the Água Forte stream, which was renewed monthly. The floating beds consisted in a high-density polyethylene floating system and an organic plant support mat filled with a plant density of 285 plants $\mathrm{m}-2$. The heavy metal removal rates obtained from the Vetiveria zizanioides and Phragmites australis floating bed were $\mathrm{Fe}=40 \% ; \mathrm{Zn}=33 \% ; \mathrm{Cu}=23 \% ; \mathrm{Mn}=14 \%$ and $\mathrm{Fe}=27 \%$; $\mathrm{Zn}=19 \% ; \mathrm{Mn}=17 \% ; \mathrm{Cu}=14 \%$; respectively. The order of heavy metals accumulation in Vetiveria zizanioides and Phragmites australis in plant biomass was $\mathrm{Fe}>\mathrm{Zn}>\mathrm{Cu}>\mathrm{Mn}$ and $\mathrm{Fe}>\mathrm{Zn}>\mathrm{Mn}>\mathrm{Cu}$, respectively. The growth of Vetiveria zizanioides and Phragmites australis in leaf biomass was $7.1 \pm 0.3 \mathrm{~cm} / \mathrm{month}$ and $2.5 \pm 0.0 \mathrm{~cm} / \mathrm{month}$ and in root biomass $3.8 \pm 0.1 \mathrm{~cm} /$ month and $4.1 \pm 0.1 \mathrm{~cm} / \mathrm{month}$, respectively. The growth of macrophytes showed the ability to survive in the AMD-containing waters without severe damage in their external and anatomical morphology, although their growth suffered inhibition. The results suggest that the floating bed technology may be an environmentally sustainable alternative, allowing long-term heavy metal removal.
\end{abstract}

Keywords: floating beds; heavy metals; Phragmites australis; Vetiveria zizanioides; Água Forte stream

\section{INTRODUCTION}

Mining is a major source of pollution, causing significant changes in the surrounding environment. Mines often cause severe impacts on soil, water resources and aquatic communities. The water quality is directly or indirectly affected by the mobilization and transport of sediment in runoff, atmospheric dust deposition or, mainly, acidification due to the leaching of the exposed sulfated rocks (Werner, Bebbington, \& Gregory, 2019).

The Iberian Pyrite Belt (IPB) is the metallogenic province that occupies a vast swath of the Iberian Peninsula SW (from the Caveira Mine in Portugal to Aznalcóllar in Spain), where numerous polymetallic massive sulfide deposits associated with volcanic rocks of the Vulcano-Sedimentary Complex are found, In Portugal, there are two important active mines, Aljustrel and Neves-Corvo. The Aljustrel mining area represents a major environmental concern, as it presents both open and underground structures with acid mine drainage (AMD) events (Maia et al., 2012).

The result of AMD poses severe problems of environmental pollution due to its high acidity, toxic metals and sulfate content (Werner et al., 2019). Arsenic (As), copper (Cu), iron (Fe), manganese $(\mathrm{Mn})$, lead $(\mathrm{Pb})$, zinc $(\mathrm{Zn})$ and sulfates $\left(\mathrm{SO}_{4}{ }^{2-}\right)$ are often found in high concentrations in acidified waters and their solubility increases 
with acidity (Gorito et al., 2017). Heavy metals are particularly problematic due to their persistence in the environment and their non-biodegradability (Joseph et al., 2019).

The Roxo stream, located on the right bank of the Sado River (Portugal), has been heavily influenced by mining and the agricultural activity in the region. One of the tributaries of the Roxo stream that has contributed to the decrease in the water quality is the Água Forte stream.

It has poor water quality (Instituto da Água, 2009), not only caused by agriculture and livestock, but also due to the Aljustrel mining activity. As a result, the surrounding area is highly degraded and the agricultural productivity is negatively affected. Thus, solving this problem by using effective and environmentally sustainable pollutant removal solutions is considered relevant.

Eco-rehabilitation features a sustainable use of the natural and / or built ecosystems for environmental protection and restoration. Ecological remediation technologies include the phytoremediation mechanisms (floating beds treatment wetland (FTW) and artificial wetlands (ZHA), among others), biomanipulation and various combined techniques (Ning et al., 2014).

The FTW have been used in many locations and in wide variety. FTWs are made up of floating matrices (floating bed), which are associated with ecological communities such as macrophytes and microorganisms (Kadlec \& Wallace, 2009). The FTWs have been used since the 1900s in the US and 1920 in Japan (Ning et al., 2014), but are currently considered as an affordable and environmentally friendly technology for surface water eco-remediation (Walker et al., 2017).
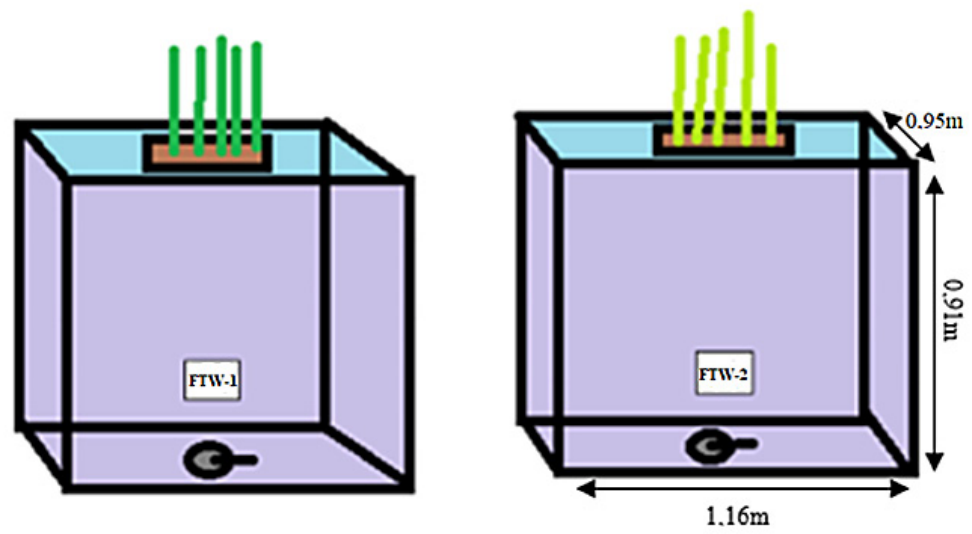

Figure 1. General scheme of pilot installation: (FTW-1) containing the floating bed with Phragmites australis and the water from the Água Forte stream $\left(0.8 \mathrm{~m}^{3}\right)$ and (FTW-2) containing the floating bed with Vetiveria zizanioides and the water from the Água Forte stream $\left(0.8 \mathrm{~m}^{3}\right)$
Currently, many macrophyte species, especially the high growth rate macrophytes, are being investigated to determine their potential and efficacy. They can be classified as submerged, floating and emerging macrophytes. In this study, the emerging macrophytes Vetiveria zizanioides and Phragmites australis were used, because both plants have high tolerance towards the elevated concentrations of heavy metals such as As, $\mathrm{Cd}, \mathrm{Cu}, \mathrm{Cr}, \mathrm{Pb}, \mathrm{Hg}, \mathrm{Ni}$, Se and $\mathrm{Zn}$ (Truong et al., 2010; Bonanno, 2011; Srivastava, Kalra, \& Naraian, 2014; Vargas et al., 2016).

This study aims to evaluate, the performance of the macrophyte FTW pilot-scale installation (Vetiveria zizanioides and Phragmites australis) in the removal of heavy metals $(\mathrm{Zn}, \mathrm{Cu}, \mathrm{Fe}$ and $\mathrm{Mn}$ ) in order to contribute to the improvement of the quality of water from the Água Forte stream.

\section{MATERIAL AND METHODS}

\section{Experimental setup}

The experimental work was carried out over 6 months (January to June of 2019) in two identical pilot-scale FTWs with a floating bed (area of $0.28 \mathrm{~m}^{2}$ each), filled with Phragmites australis $(F T W-1)$ and Vetiveria zizanioides (FTW-2) (Figure 1), using a plant density of 286 plants $\mathrm{m}^{-2}$. The experiments were performed outdoors and both tanks ( $6.04 \mathrm{~m}^{2}$ each) were filled with $0.8 \mathrm{~m}^{3}$ of water from the Água Forte stream. The control water (tributary) was the water of the Água Forte stream renewed monthly. 


\section{Water characterization}

Table 1 shows the physicochemical characterization of the Água Forte stream water.

The multiparameter portable probe (HI9829 HANNA) was used for measuring the following parameters: $\mathrm{pH}$; water temperature (Tw); redox potential (Eh); Electrical conductivity (EC); Dissolved Oxygen (DO) and Total Dissolved Solids (TDS).

The remaining parameters were determined according to Standard Methods for the Examination of Water and Effluents (APHA, 2005), including: Sodium $\left(\mathrm{Na}^{+}\right)$; Potassium $\left(\mathrm{K}^{+}\right)$; Magnesium $\left(\mathrm{Mg}^{2+}\right)$; Calcium $\left(\mathrm{Ca}^{2+}\right)$; Total Suspended Solids (SST); Chlorides $\left(\mathrm{Cl}^{-}\right)$; Ammoniacal Nitrogen $\left(\mathrm{NH}_{4}^{+}\right)$; Kjeldhal nitrogen $(\mathrm{Nkj})$; Nitrates $\left(\mathrm{NO}_{3}^{-}\right)$; Nitrite $\left(\mathrm{NO}_{2}^{-}\right)$; Phosphorus (P); Phosphate $\left(\mathrm{PO}_{4}^{3-}\right)$; Boron $\left(\mathrm{B}^{3+}\right)$; Chemical Oxygen Demand (COD); Biochemical Oxygen Demand $\left(\mathrm{BOD}_{5}\right)$; Sulphides $\left(\mathrm{S}^{2-}\right)$; Sulphites $\left(\mathrm{SO}_{3}{ }^{2-}\right)$; Thiosulphates $\left(\mathrm{S}_{2} \mathrm{O}_{3}{ }^{2-}\right)$; Sulphates $\left(\mathrm{SO}_{4}{ }^{3-}\right)$; Zinc $(\mathrm{Zn})$; Copper $(\mathrm{Cu})$; Manganese $(\mathrm{Mn})$ and Iron $(\mathrm{Fe})$.

According to the physicochemical parameters analyzed the water from the Água Forte stream, it appears to have typical characteristics of a water affected by a AMD, because it contains high concentrations of $\mathrm{SO}_{4}{ }^{2-}\left(826 \pm 31 \mathrm{mg} \mathrm{L}^{-1}\right)$; low $\mathrm{pH}(3.2 \pm 0.1)$, high concentrations of $\mathrm{Zn}\left(13 \pm 2 \mathrm{mg} \mathrm{L}^{-1}\right)$ and Fe $\left(8 \pm 0.0 \mathrm{mg} \mathrm{L}^{-1}\right)$ and low concentrations of macronutrients.
The most important physicochemical water quality parameters related to the heavy metal removal, include $\mathrm{pH}$, temperature, electrical conductivity (EC), dissolved oxygen (DO) and redox potential (Eh) (Joseph et al., 2019).

\section{Pre-treatment of Vetiveria zizanioides and Phragmites australis}

The amount of Vetiveria zizanioides used in this study was 80 feet. They were purchased in December 2018, with small size and showing incipient signs of chlorosis. An equal amount of Phragmites australis from the School of Agriculture (IPBeja) was used, with signs of senescence, probably due to the decrease in temperature in December.

Vetiveria zizanioides and Phragmites australis were washed, placed in $0.01 \mathrm{~m}^{3}$ tanks of distilled water and nutrient solution for three weeks; then, it was gradually mixed with progressively larger amounts of water from the Água Forte stream.

\section{Laboratory Analysis}

\section{Water Sampling}

The water sampling was done monthly. A $50 \mathrm{~mL}$ of water sample for heavy metal analysis was obtained and filtered using $0.45 \mu \mathrm{m}$ cellulose acetate filter paper to remove large materials, which could cause interference by reacting

Table 1. General characterization of the water quality of the Água Forte stream (Mean \pm SD: $n=6)$

\begin{tabular}{|c|c|c|c|c|c|}
\hline Parameters & Units & $\begin{array}{c}\text { Quality of Água Forte } \\
\text { Stream }\end{array}$ & Parameters & Units & $\begin{array}{c}\text { Quality of Água Forte } \\
\text { Stream }\end{array}$ \\
\hline $\mathrm{pH}$ & Sorensen Scale & $3.2 \pm 0.1$ & $\mathrm{~S}^{-2}$ & $\mathrm{mg} / \mathrm{L}$ & $2 \pm 0.0$ \\
\hline $\mathrm{T}_{\mathrm{w}}$ & ${ }^{\circ} \mathrm{C}$ & $17 \pm 2$ & $\mathrm{SO}_{3}{ }^{2-}$ & $\mathrm{mg} / \mathrm{L}$ & $15 \pm 3$ \\
\hline Eh & $\mathrm{mV}$ & $522 \pm 19$ & $\mathrm{~S}_{2} \mathrm{O}_{3}{ }^{2-}$ & $\mathrm{mg} / \mathrm{L}$ & $4 \pm 0.0$ \\
\hline $\mathrm{B}$ & $\mathrm{mg} / \mathrm{L}$ & $0.3 \pm 0.1$ & $\mathrm{SO}_{4}^{2-}$ & $\mathrm{mg} / \mathrm{L}$ & $826 \pm 31$ \\
\hline EC & $\mu \mathrm{S} / \mathrm{cm} 20^{\circ} \mathrm{C}$ & $1813 \pm 117$ & $\mathrm{~F}^{-}$ & $\mathrm{mg} / \mathrm{L}$ & $1 \pm 0.0$ \\
\hline $\mathrm{HCO}_{3}^{-}$ & - & $0 \pm 0.0$ & $\mathrm{Cl}^{-}$ & $\mathrm{mg} / \mathrm{L}$ & $208 \pm 21$ \\
\hline $\mathrm{CO}_{3}^{2-}$ & - & $0 \pm 0.0$ & SST & $\mathrm{mg} / \mathrm{L}$ & $17 \pm 1$ \\
\hline $\mathrm{DO}$ & $\mathrm{mg} / \mathrm{L}$ & $7 \pm 1$ & SDT & $\mathrm{mg} / \mathrm{L}$ & $1238 \pm 232$ \\
\hline $\mathrm{DO}$ & $\mathrm{O}_{2}$ saturation $\%$ & $81 \pm 1$ & $\mathrm{Na}^{+}$ & $\mathrm{mg} / \mathrm{L}$ & $102 \pm 16$ \\
\hline DQO & $\mathrm{mg} / \mathrm{L} \mathrm{O}_{2}$ & $30 \pm 3$ & $\mathrm{~K}^{+}$ & $\mathrm{mg} / \mathrm{L}$ & $11 \pm 2$ \\
\hline $\mathrm{DBO}_{5}$ & $\mathrm{mg} / \mathrm{L} \mathrm{O}_{2}$ & $4 \pm 0,0$ & $\mathrm{Ca}^{2+}$ & $\mathrm{mg} / \mathrm{L}$ & $109 \pm 19$ \\
\hline $\mathrm{PO}_{4}^{3-}$ & $\mathrm{mg} / \mathrm{L}$ & $0.007 \pm 0.001$ & $\mathrm{Mg}^{2+}$ & $\mathrm{mg} / \mathrm{L}$ & $76 \pm 8$ \\
\hline$P_{\text {total }}$ & $\mathrm{mg} / \mathrm{L}$ & $0.009 \pm 0.001$ & $\mathrm{Zn}$ & $\mathrm{mg} / \mathrm{L}$ & $13 \pm 2$ \\
\hline $\mathrm{Nkj}$ & $\mathrm{mg} / \mathrm{L}$ & $11 \pm 0.0$ & $\mathrm{Fe}$ & $\mathrm{mg} / \mathrm{L}$ & $8 \pm 0.0$ \\
\hline $\mathrm{NO}_{2}^{-}$ & $\mathrm{mg} / \mathrm{L}$ & $0.03 \pm 0.0$ & $\mathrm{Cu}$ & $\mathrm{mg} / \mathrm{L}$ & $3 \pm 0.0$ \\
\hline $\mathrm{NH}_{4}^{+}$ & $\mathrm{mg} / \mathrm{L}$ & $9 \pm 2$ & $\mathrm{Mn}$ & $\mathrm{mg} / \mathrm{L}$ & $7 \pm 1$ \\
\hline $\mathrm{NO}_{3}^{-}$ & $\mathrm{mg} / \mathrm{L}$ & $7 \pm 1$ & - & - & - \\
\hline
\end{tabular}


with the analytes during storage as well as prerequirement for analysis by an atomic absorption spectrometry (AAS) according to Standard Methods for the Examination of Water and Effluents (APHA, 2005). The water samples were then acidified to $\mathrm{pH}<2$ by adding $10 \mathrm{~mL} \mathrm{HNO}_{3} \mathrm{Su}-$ prapur 65\% (Appelo \& Postma, 2004) in order to preserve most elements by reducing precipitation and adsorption losses to container walls and also to avoid the microbial activity.

\section{Plant Harvesting}

The plants were harvested for each treatment and rinsed with tap water, followed by deionized water, to wash off any substances deposited on the shoots and residual heavy metal on the root surface. The plant biomass was separated in two samples, which consist of leaves and roots. The wet weight of each sample was obtained using analytical balance. The leaves and roots were dried at $70-85^{\circ} \mathrm{C}$ in the oven to a constant weight.

The total harvestable dry biomass was then determined by the dry weight $(D W)$ of each sample. Then, $2 \mathrm{~g}$ of the samples was digested with $10 \mathrm{~mL}$ concentrated hydrochloric acid ( $\mathrm{HCl} 30 \%)$. The acid digestion was carried out in a fume cupboard using a digestion block at $90^{\circ} \mathrm{C}$ for $2 \mathrm{~h}$. The digestate was then cooled at room temperature before being filtered using $0.45 \mu \mathrm{m}$ cellulose acetate filter paper via syringe filter. Then, the filtered sample was adjusted with the addition of the Milli-Q ${ }^{\circledR}$ water to a final volume of $100 \mathrm{~mL}$..

\section{Heavy Metal Analysis}

The samples were analyzed for heavy metal concentration by using AAS (SpectrAA 220FSVarian). The concentration of heavy metal in plants was calculated on a dry weight basis as shown in Eq. 1 below (Ayeni et al., 2012).

$$
\begin{gathered}
\mathrm{C}_{(\mathrm{mg} / \mathrm{kg})}= \\
\frac{\left(\text { Heavy metal conc.from AAS }\left(\frac{m g}{L}\right)-\operatorname{Blank}\left(\frac{m g}{L}\right)\right) \times \operatorname{Vsample}(\mathrm{L})}{\text { Dry Weight of sample }(\mathrm{kg})}
\end{gathered}
$$

\section{Data Analysis}

\section{Biomass production measurements}

Plant biomass production $\operatorname{Pr}\left(\mathrm{g}_{\mathrm{DW}} \cdot \mathrm{m}^{-2}\right)$ was calculated as follows:

$$
\operatorname{Pr}=\frac{D W_{2}-D W_{1}}{A}
$$

where $D W_{1}$ and $D W_{2}$ are dry plants weight (g) at the beginning and end of the study, respectively, and $A$ is the floating bed area.

\section{Removal Efficiency}

The removal of metals was calculated using the following equation (Parnian et al., 2016):

$$
R(\%)=\frac{C_{0}-C_{f}}{C_{0}} \times 100
$$

where $C_{0}$ and $C_{f}$ represent the concentration of metal at the beginning and at the final of the experiment, respectively.

\section{Bioconcentration Factor and Translocation Factor}

Bioconcentration is applied as a criterion to define the accumulative tendency of chemicals in an aquatic environment. It is the result of the uptake, distribution and elimination of water-borne chemicals by aquatic organisms.

The Bioconcentration Factor $(B C F)$ is defined as the ratio of the chemical concentration in an organism to the concentration in water at steadystate (Y. Wang et al., 2014). The $B C F$ was calculated as follows (Khellaf \& Zerdaoui, 2009):

$B C F=\frac{\text { Metal concentration in plant biomass }(\mathrm{mg} / \mathrm{Kg} \mathrm{DW})}{\text { Metal concentration in water }(\mathrm{mg} / \mathrm{L})}$

The Translocation Factor $(T F)$ is a relationship between the plant ability to extract heavy metals from the root to the shoot. $T F<1$ means that most heavy metals accumulate at the root and vice versa. The $T F$ was calculated as follows (Arivoli, Mohanraj \& Seenivasan, 2015):

$T F=\frac{\text { Metal concentration in plant leaf biomass }(\mathrm{mg} / \mathrm{Kg} \mathrm{DW})}{\text { Metal concentration in plant root biomass }(\mathrm{mg} / \mathrm{Kg} \mathrm{DW})}$

\section{Statistical Analysis}

Standard deviations, correlation and regression analysis were performed using Microsoft Excel, Office 2016 and "Statistica 10.0" software package (StatSoft, Inc., USA). One-way ANOVA was performed to identify significant differences in metal concentrations in different treatments. The differences were considered significant at $\mathrm{p}<0.05$. Tukey's test was used to determine the differences between the means of specific variables. 


\section{RESULTS AND DISCUSSION}

\section{Metals removal from water}

The heavy metal accumulation in agricultural soils and water resources poses a major threat to the human health due to the potential risk of their entering the food chain (Sarwar et al., 2017).

The treatment efficiency in removing metals or reducing the metal toxicity is easily influenced by internal and external environmental conditions such as water quality, biological activity, season and operational strategies (Xu \& Mills, 2018).
Figure 2 shows the evolution of the monthly average values of Manganese (Mn), Zinc ( $\mathrm{Zn})$, Copper $(\mathrm{Cu})$ and Iron $(\mathrm{Fe})$ in the control (Affluent), in $F T W-1$ and $F T W-2$, during the monitoring period (6 months).

The mean monthly $\mathrm{Mn}$ concentration in the control was $7.3 \pm 0.5 \mathrm{mg} \cdot \mathrm{L}^{-1}, F T W-1$ of $6.1 \pm 0.7 \mathrm{mg} \cdot \mathrm{L}^{-1}$ and $F T W-2$ of $6.3 \pm 0.4 \mathrm{mg} \cdot \mathrm{L}^{-1}$, showing a removal efficiency of $17 \%$ for $F T W-1$ and $14 \%$ for $F T W-2$.

The Mn removal was most noticeable in, FTW-1 because Phragmites australis can remove high Mn concentrations (Srivastava et al., 2014).
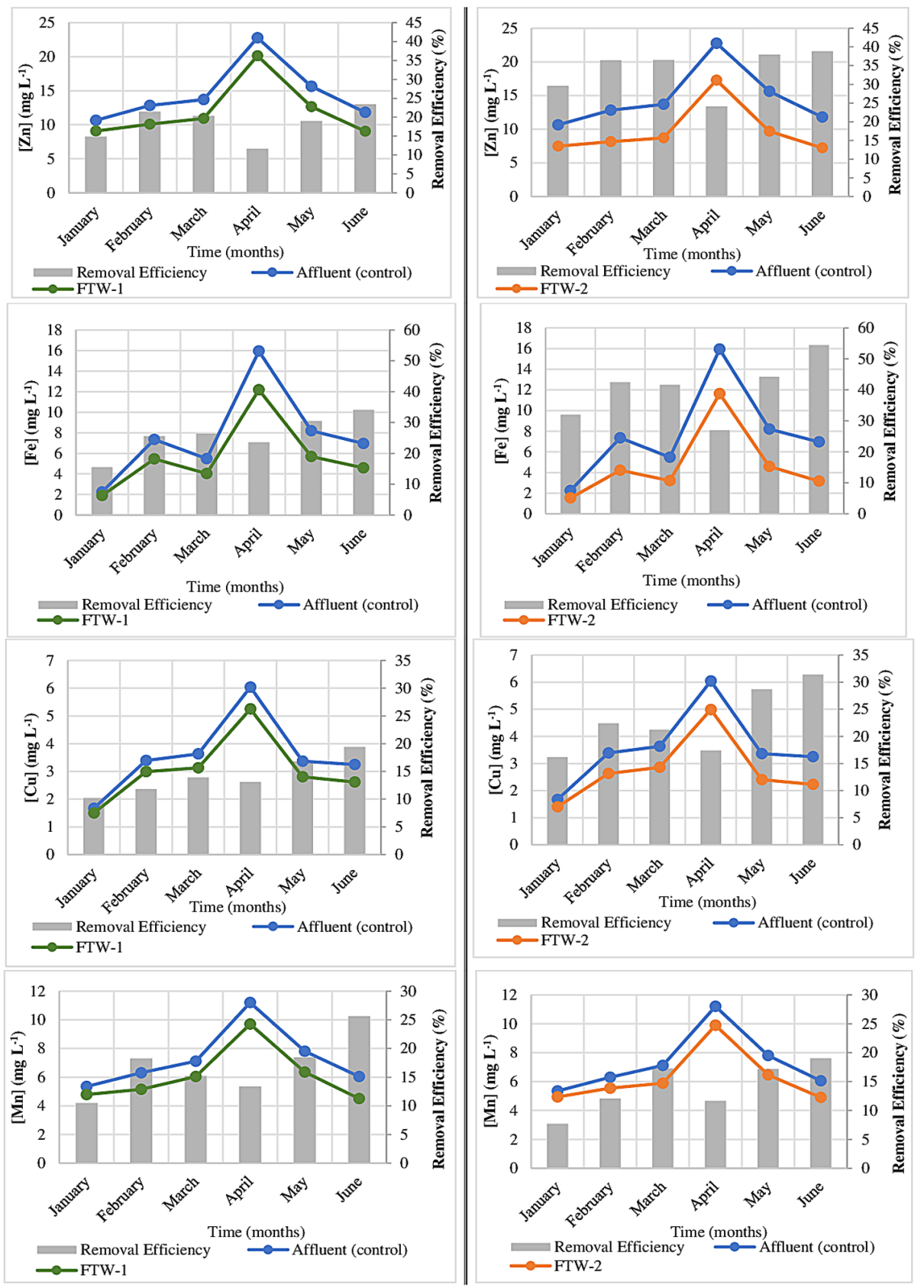

Figure 2. Evolution of Manganese (Mn), Copper (Cu), Zinc ( $\mathrm{Zn})$ and Iron $(\mathrm{Fe})$ metal contents and their removal efficiency in the Affluent (control), FTW-1 and FTW-2 water, during the monitoring period (Mean \pm SD, $n=3$ ) 
$\mathrm{Zn}$ had a monthly mean value in the control of $14.6 \pm 0.6 \mathrm{mg} \cdot \mathrm{L}^{-1}, F T W-1$ of $11.9 \pm 0.9 \mathrm{mg} \cdot \mathrm{L}^{-1}$ and $F T W-2$ of $9.7 \pm 0.7 \mathrm{mg} \cdot \mathrm{L}^{-1}$, revealing an average removal efficiency of $19 \%$ and $33 \%$, respectively.

$\mathrm{Cu}$ had a monthly mean value in the control of $3.6 \pm 0.2 \mathrm{mg} \cdot \mathrm{L}^{-1}, F T W-1$ of $3.6 \pm 0.4 \mathrm{mg} \cdot \mathrm{L}^{-1}$ and $F T W-2$ of $3.1 \pm 0.3 \mathrm{mg} \cdot \mathrm{L}^{-1}$, showing an average removal efficiency of $14 \%$ for $F T W-1$ and $23 \%$ for $F T W-2$.

Fe presented a monthly mean value in the control of $7.7 \pm 0.4 \mathrm{mg} \cdot \mathrm{L}^{-1}, F T W-1$ of $5.7 \pm 0.9 \mathrm{mg} \cdot \mathrm{L}^{-1}$ and $F T W-2$ of $4.7 \pm 0.7 \mathrm{mg} \cdot \mathrm{L}^{-1}$, showing an average removal efficiency of $27 \%$ for $F T W-1$ and $40 \%$ for $F T W-2$.

In general, it was found that in April there was a reduction in the removal efficiency of all studied metals, which may be related to a higher affluent load, due to eventual runoff, resulting from the rain period in April $(62.1 \mathrm{~mm})$, and/or a more concentrated discharge of mining activity. Although there was a decrease in metals in both $F T W$, in statistical terms there was no significant variation $(\mathrm{p}>0.05)$.

\section{Metals accumulation in plants biomass}

The accumulation of heavy metals by macrophytes depends on the absorption capacity and intracellular transport of a plant, and involves several steps: (i) plant root immobilization; (ii) transport of metals by the root cell plasma membrane; (iii) xylem loading and translocation; and (iv) plant-wide and cellular-level detoxification and sequestration of heavy metals (Vymazal \& Březinová, 2016).

The heavy metal concentrations found in Phragmites australis and Vetiveria zizanioides leaf and root biomass after the 6 months of the experiments are shown in Tables 2 and $3\left(\mathrm{mg} \mathrm{kg}^{-1} D W\right)$.

In the two species studied, the following monthly accumulation order was observed: $\mathrm{Fe}>\mathrm{Zn}>\mathrm{Cu}>\mathrm{Mn}$ for leaf and root biomass of Vetiveria zizanioides and $\mathrm{Fe}>\mathrm{Zn}>\mathrm{Mn}>\mathrm{Cu}$ for root and leaf biomass of Phragmites australis. In a similar study, (Darajeh et al., 2019) had an order of accumulation of $\mathrm{Fe}>\mathrm{Zn}>\mathrm{Pb}>\mathrm{Mn}>\mathrm{Cu}$ with Vetiveria zizanioides.

The Fe concentration is the highest in both plants, comparing with the other metals. This may be because this element is highly needed at the beginning of growth of plants (Darajeh et al., 2014). Although some metals showed higher plant uptake values than others, Vetiveria $z i$ zanioides has indicated higher absorption/adsorption efficiency than Phragmites australis.

In fact, the differences in the uptake of metal ions by plants and between plant species are genetically controlled and influenced by the joint and simultaneous action of various factors, such as ambient and ambient temperature, plant growth dynamics, concentration variations. of metals available in water and solar radiation intensity, among others (Bragato, Brix, \& Malagoli, 2006; Golubev, 2011).

In both macrophytes, $\mathrm{Fe}$ and $\mathrm{Zn}$ showed the highest accumulation in the root and leaf

Table 2. Total root accumulated heavy metal content $\left(\mathrm{mg} \mathrm{kg}^{-1} \mathrm{DW}\right)$ of Vetiveria zizanioides and Phragmites australis

\begin{tabular}{|c|c|c|}
\hline \multicolumn{2}{|c|}{ Roots } \\
\hline Element & Vetiveria zizanioides ${ }^{1}$ & Phragmites australis $^{1}$ \\
\hline $\mathrm{Zn}$ & $955 \pm 13 \mathrm{a}$ & $458 \pm 34 \mathrm{~b}$ \\
\hline $\mathrm{Cu}$ & $147 \pm 7 \mathrm{a}$ & $74 \pm 4 \mathrm{a}$ \\
\hline $\mathrm{Fe}$ & $1020 \pm 18 \mathrm{a}$ & $666 \pm 15 \mathrm{~b}$ \\
\hline $\mathrm{Mn}$ & $100 \pm 5 \mathrm{a}$ & $201 \pm 3 \mathrm{a}$ \\
\hline \multicolumn{2}{|c|}{} \\
\hline
\end{tabular}

Table 3. Total leaf accumulated heavy metal content $\left(\mathrm{mg} \mathrm{kg}^{-1} \mathrm{DW}\right)$ of Vetiveria zizanioides and Phragmites australis

\begin{tabular}{|c|c|c|}
\hline \multirow{2}{*}{ Element } & \multicolumn{2}{|c|}{ Leaves } \\
\hline & Vetiveria zizanioides $^{1}$ & Phragmites australis 1 \\
\hline$Z n$ & $227 \pm 5 a$ & $115 \pm 4 a$ \\
\hline $\mathrm{Cu}$ & $37 \pm 2 a$ & $19 \pm 1 a$ \\
\hline $\mathrm{Fe}$ & $265 \pm 4 a$ & $166 \pm 15 a$ \\
\hline$M n$ & $25 \pm 1 a$ & $50 \pm 3 a$ \\
\hline
\end{tabular}


biomass. These results agree with the literature, which states that $\mathrm{Fe}$ and $\mathrm{Zn}$ show a higher assimilation capacity in both plants, compared to the other metals analyzed (Wang \& Jia, 2009; Srivastava et al., 2014; Suelee et al., 2017). It was also found that the accumulation preferably occurred at the roots.

The results obtained were lower than those reported in the literature, although the experimental conditions are not coincident with the present study. Suelee et al., (2017), reports that at high concentrations of metals in synthetic medium after 10 days, Vetiveria zizanioides had a Fe accumulation of $19197 \mathrm{mg} \cdot \mathrm{kg}^{-1} \mathrm{DW}$ in the root and $1549 \mathrm{mg} \cdot \mathrm{kg}^{-1} \mathrm{DW}$ in the leaf. Likewise, the content of $\mathrm{Cu}, \mathrm{Mn}$ and $\mathrm{Zn}$ in the root was $1110 \mathrm{mg} \mathrm{kg}^{-1}$, $826 \mathrm{mg} \cdot \mathrm{kg}^{-1}$ and $705 \mathrm{mg} \cdot \mathrm{kg}^{-1} \mathrm{DW}$, respectively, and in the $458 \mathrm{mg} \cdot \mathrm{kg}^{-1} \mathrm{DW}$ sheet, $409 \mathrm{mg} \cdot \mathrm{kg}^{-1} \mathrm{DW}$ and $278 \mathrm{mg} \cdot \mathrm{kg}^{-1} \mathrm{DW}$, respectively.

Phragmites australis generally had lower accumulation values, except for $\mathrm{Mn}$ which showed $251 \mathrm{mg} \cdot \mathrm{kg}^{-1} \mathrm{DW}$, much higher than that observed in Vetiveria zizanioides of $126 \mathrm{mg} \cdot \mathrm{kg}^{-1} \mathrm{DW}$. Srivastava et al., (2014) mentions that the macrophyte Phragmites australis is very tolerant to high $\mathrm{Mn}$ concentrations and can accumulate large concentrations of Mn metals in its tissues.

OGuo \& Cutright, (2014) mentions that using Phragmites australis for the $\mathrm{Fe}$ and $\mathrm{Mn}$ removal in a mine water yielded the root concentrations of $2390 \mathrm{mg} \cdot \mathrm{kg}^{-1} \mathrm{DW}$ and $80 \mathrm{mg} \cdot \mathrm{kg}^{-1}$ DW, respectively. For leaves $200 \mathrm{mg} \cdot \mathrm{kg}^{-1} \mathrm{DW}$ and $40 \mathrm{mg} \cdot \mathrm{kg}^{-1} \mathrm{DW}$ was obtained, respectively.
On the other hand, under the conditions similar to the previous study, Nyquist \& Greger, (2009) obtained the $\mathrm{Zn}$ and $\mathrm{Cu}$ concentrations in the root of $2524 \mathrm{mg} \cdot \mathrm{kg}^{-1} \mathrm{DW}$ and $300 \mathrm{mg} \cdot \mathrm{kg}^{-1} \mathrm{DW}$, respectively, and in the leaves of $148 \mathrm{mg} \cdot \mathrm{kg}^{-1} \mathrm{DW}$ and $34 \mathrm{mg} \cdot \mathrm{kg}^{-1} \mathrm{DW}$, respectively. Comparing these two studies with the results obtained, only the concentration of $\mathrm{Mn}$ in both parts of the plant is above the previously mentioned value.

Figures 3 and 4 show the evolution of BCF $\left(\mathrm{L} \cdot \mathrm{kg}^{-1}\right)$ and $\mathrm{TF}$ of Vetiveria zizanioides and Phragmites australis for the $\mathrm{Zn}, \mathrm{Cu}, \mathrm{Fe}$ and $\mathrm{Mn}$ metals, respectively.

These figures clearly show that the FBC values increased over the months. However, Vetiveria zizanioides, showed a sharp decrease in April, probably due to the increase of concentration of metals in the tributary.

In the study by Alexandre, (2016), using Phragmites australis in ZHA to treat mining water, it was found that the values of BCF are higher than 1 , reaching higher values at the hottest months of the year (July and August).

In this study, it was observed that the values of $\mathrm{BCF}$ in Vetiveria zizanioides are higher than Phragmites australis. The reasons why the BCF values were lower in Phragmites australis can be explained by the dormancy of the plant that lasted until April, with improvements in May and June. The metals with the highest FBC value were $\mathrm{Zn}$ and $\mathrm{Fe}$, mainly in Vetiveria zizanioides, which indicates that these metals are more
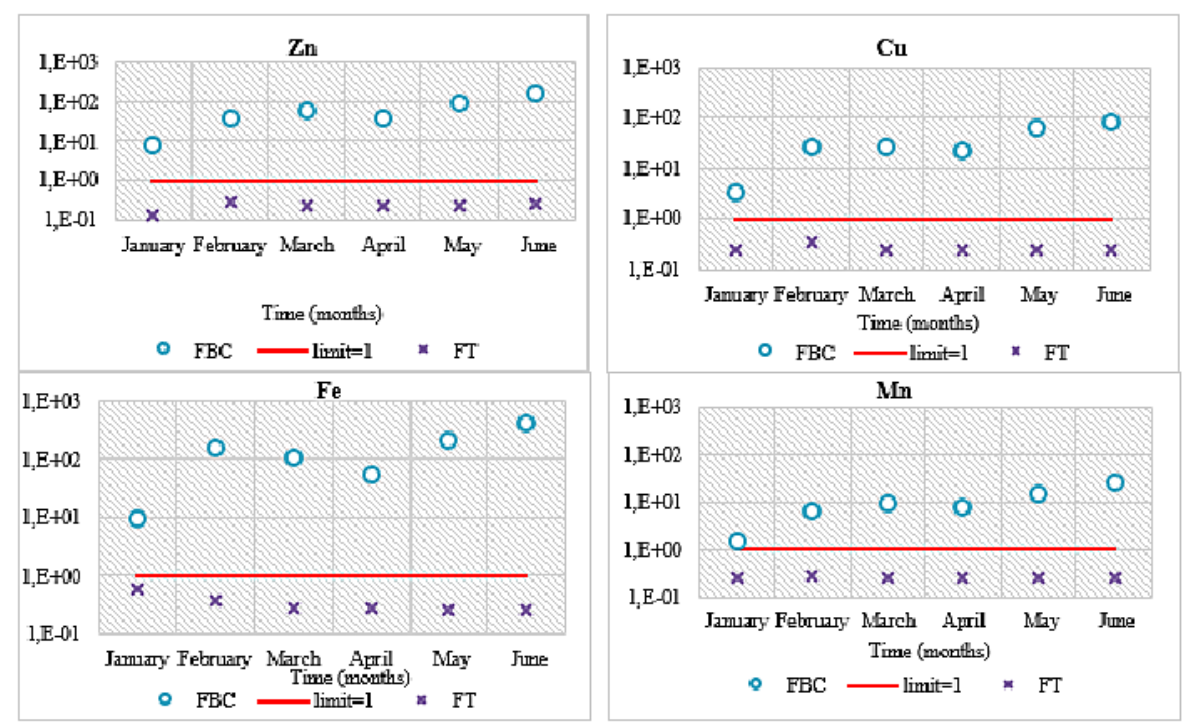

Figure 3. Evolution of Bioconcentration Factor (BCF) and Translocation Factor (TF) in Vetiveria zizanioides for the metals: $\mathrm{Zn}, \mathrm{Cu}, \mathrm{Fe}$ and $\mathrm{Mn}$ 


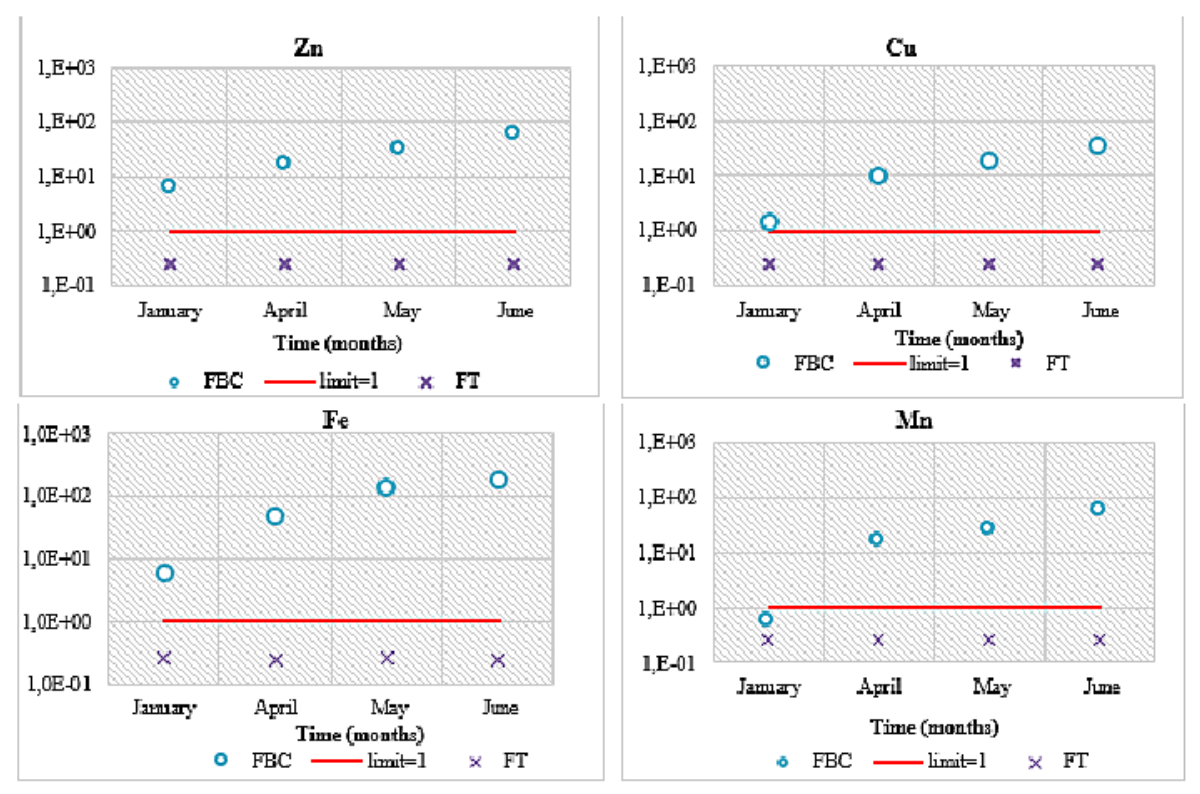

Figure 4. Evolution of Bioconcentration Factor (BCF) and Translocation Factor (TF) in Phragmites australis for the elements: $\mathrm{Zn}, \mathrm{Cu}, \mathrm{Fe}$ and $\mathrm{Mn}$

easily accumulated in macrophyte tissues than other elements. According to a study by Suelee, (2016), it obtained higher BCF for Fe using a synthetic water and the macrophyte Vetiveria zizanioides.

\section{Plants growth and biomass production}

The structure and composition of macrophytes can provide the information on the trophic and environmental health, its alteration and evolution (Buosi \& Sfriso, 2017).

Figure 5 shows the evolution of the average growth of root and leaf biomass of Phragmites australis and Vetiveria zizanioides.

The root growth rate in Phragmites australis and Vetiveria zizanioides was $4.1 \pm 0.1 \mathrm{~cm} /$ month and $3.8 \pm 0.1 \mathrm{~cm} /$ month, respectively, with higher root growth in Phragmites australis. For the leaf biomass there was a growth rate in Phragmites australis of $2.5 \pm 0.0 \mathrm{~cm} / \mathrm{month}$ and in Vetiveria zizanioides $7.1 \pm 0.1 \mathrm{~cm} / \mathrm{month}$. During the first three months of monitoring, the Phragmites australis leaf biomass remained constant and the root biomass grew significantly compared to Vetiveria zizanioides. The first leaf shoots of Phragmites australis were observed at the end of March, which coincided with the end of the dormancy period of the plant.

Table 4 shows the total leaf and root biomass production during the monitoring period. The table analysis suggests that the average concentrations of metals in leaf and root biomass in both plants were generally lower than those reported in the literature (Nyquist \& Greger, 2009; Guo \& Cutright, 2014; Suelee et al., 2017). However, Vetiveria zizanioides performed better than Phragmites australis.
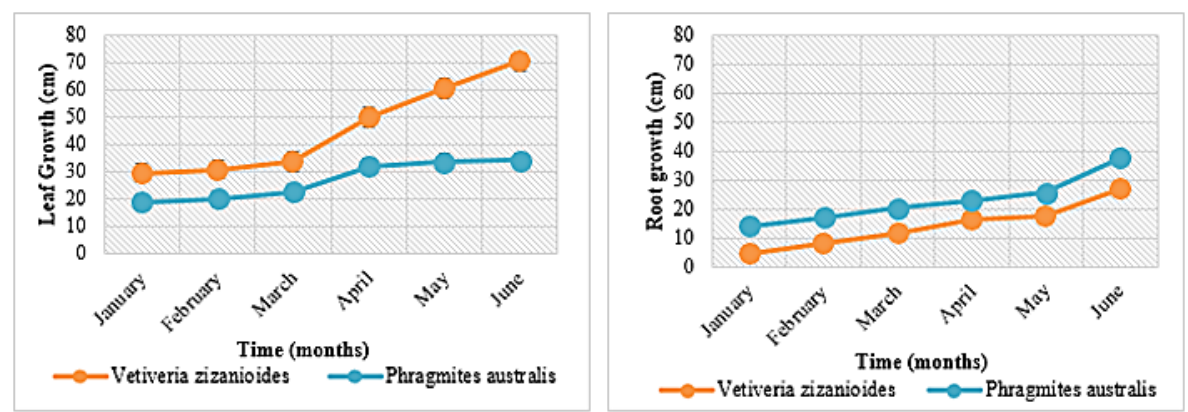

Figure 5. Growth of root and leaf biomass of Vetiveria zizanioides and Phragmites australis (Mean $\pm \mathrm{SD}, \mathrm{n}=3$ ) 
Table 4. Total leaf and root biomass production (Mean $\pm \mathrm{SD}, \mathrm{n}=6$ )

\begin{tabular}{|c|c|c|c|c|c|}
\hline \multicolumn{5}{|c|}{ Macrophyte } \\
\hline \multicolumn{3}{|c|}{ Phragmites australis $\left(\mathrm{g} \mathrm{m}^{-2} \mathrm{DW}\right)$} & \multicolumn{3}{c|}{ Vetiveria zizanioides $\left(\mathrm{g} \mathrm{m}^{-2} \mathrm{DW}\right)$} \\
\hline Leaf & Root & Total & Leaf & Root & Total \\
\hline $515 \pm 24$ & $2728 \pm 196$ & $3243 \pm 220$ & $1041 \pm 48$ & $3858 \pm 254$ & $4859 \pm 302$ \\
\hline
\end{tabular}

According to Danh et al., (2009) under hot and humid tropical conditions, Vetiveria zizanioides grows very rapidly, reaching extremely high biomass yields (over $10,000 \mathrm{~g} \cdot \mathrm{m}^{-2} \cdot \mathrm{yr}^{-1} \mathrm{DW}$ ); however, Phragmites australis can produce $6250 \mathrm{~g} \cdot \mathrm{m}^{-2} \mathrm{DW}$ in a short time (Moore et al., 2012).

The inhibition of growth and biomass production in both macrophytes can be explained by: (i) low temperatures recorded in the first months of monitoring; (ii) extreme $\mathrm{pH}$ values are a stress factor for plant growth and biomass production as it may interfere with nutrient uptake mechanisms (Jampeetong, Konnerup, Piwpuan, \& Brix, 2013); (iii) appearance of algae that fixed in the root zone preventing the growth of roots and leaves and (iii) high values of heavy metals.

\section{CONCLUSIONS}

The water from the Água Forte stream was shown to have AMD characteristics, with acidic $\mathrm{pH}$, high levels of metals ( $\mathrm{Fe}, \mathrm{Zn}, \mathrm{Mn}, \mathrm{Cu}$ ), sulfates and low nutrient levels. In monitoring, the macrophyte species used in the floating bed (Vetiveria zizanioides and Phragmites australis) in a pilot plant, it was possible to verify their resistance to the characteristic values of a AMD, namely to $\mathrm{pH}$ $<4$, although sometimes presenting the signs of intolerance to major macronutrient deficit $(\mathrm{N}, \mathrm{P}$ and $\mathrm{K}$ ) and heavy metal excess ( $\mathrm{Fe}, \mathrm{Zn}, \mathrm{Mn}, \mathrm{Cu}$ ). The macrophytes showed a heavy metal assimilation capacity, with an order of heavy metal accumulation in Vetiveria zizanioides and Phragmites australis of the $\mathrm{Fe}>\mathrm{Zn}>\mathrm{Cu}>\mathrm{Mn}$ and $\mathrm{Fe}>\mathrm{Zn}>\mathrm{Mn}>$ $\mathrm{Cu}$ plant biomass, respectively. Over the monitoring period, Vetiveria zizanioides and Phragmites australis were found to have an BCF $>1$, which means they have a capacity to accumulate heavy metals; however, both plants have an $\mathrm{TF}<1$, showing that they have accumulate metals in root biomass in the detriment of leaf biomass, (Rhizofiltration). In view of the above, the macrophyte Vetiveria zizanioides showed to be a more promising in relation to Phragmites australis in treating AMD water and thus contributing to a better surface water quality.
Water improved over the 6-month monitoring period, due the removal of heavy metals. The results obtained provided evidence that the FTWs under study constituted an effective long-term, environmentally friendly, cost-effective AMD treatment system.

\section{Acknowledgements}

Publication is funded by the Polish National Agency for Academic Exchange under the International Academic Partnerships Programme from the project" Organization of the $9^{\text {th }}$ International Scientific and Technical Conference entitled Environmental Engineering, Photogrammetry, Geoinformatics - Modern Technologies and Development Perspectives".

\section{REFERENCES}

1. Alexandre, L. J. T. (2016). Fitorremediação de Águas Ácidas de Minas. Dissertação apresentada ao Instituto Superior Técnico (UL) para cumprimento dos requisitos necessários para obtenção do grau de Doutor em Engenharia do Ambiente. Obtida a 1 de outubro de 2019 (in portuguese).

2. APHA. (2005). Standard Methods for the Examination of Water and Wastewater, 21st ed.; APHA:Washington, DC, USA, 2005. American Water Works Association/American Public Works Association/Water Environment Federation. https:// doi.org/10.2105/AJPH.51.6.940-a.

3. Appelo, C. A. J., \& Postma, D. (2004). Geochemistry, groundwater and pollution, second edition. Geochemistry, Groundwater and Pollution, Second Edition. https://doi.org/10.1201/9781439833544.

4. Arivoli, A., Mohanraj, R., \& Seenivasan, R. (2015). Application of vertical flow constructed wetland in treatment of heavy metals from pulp and paper industry wastewater. Environmental Science and Pollution Research, 22(17), 13336-13343. https://doi. org/10.1007/s11356-015-4594-4.

5. Ashraf, M., Ahmad, M. S. A., \& Ozturk, M. (2010). Plant adaptation and phytoremediation. In Springer (pp. 1-481). https://doi. org/10.1007/978-90-481-9370-7.

6. Ayeni, O., Ndakidemi, P., Snyman, R., \& Odendaal, 
J. (2012). Assessment of Metal Concentrations, Chlorophyll Content and Photosynthesis in Phragmites australis along the Lower Diep River, CapeTown, South Africa. Energy and Environment Research, 2(1), 128-139. https://doi.org/10.5539/ eer.v2n1p128.

7. Bonanno, G. (2011). Trace element accumulation and distribution in the organs of Phragmites australis (common reed) and biomonitoring applications. Ecotoxicology and Environmental Safety, 74(4), 1057-1064. https://doi.org/10.1016/j. ecoenv.2011.01.018.

8. Bragato, C., Brix, H., \& Malagoli, M. (2006). Accumulation of nutrients and heavy metals in Phragmites australis (Cav.) Trin. ex Steudel and Bolboschoenus maritimus (L.) Palla in a constructed wetland of the Venice lagoon watershed. Environmental Pollution, 144(3), 967-975. https://doi.org/10.1016/j. envpol.2006.01.046.

9. Buosi, A., \& Sfriso, A. (2017). Macrophyte assemblage composition as a simple tool to assess global change in coastal areas. Freshwater impacts and climatic changes. Science of the Total Environment, 606, 559-568. https://doi.org/10.1016/j. scitotenv.2017.06.196.

10. Danh, L. T., Truong, P., Mammucari, R., Tran, T., \& Foster, N. (2009). Vetiver grass, Vetiveria zizanioides: A choice plant for phytoremediation of heavy metals and organic wastes. International Journal of Phytoremediation, 11(8), 664-691. https://doi. org/10.1080/15226510902787302.

11. Darajeh, N., Idris, A., Truong, P., Abdul Aziz, A., Abu Bakar, R., \& Che Man, H. (2014). Phytoremediation potential of Vetiver system technology for improving the quality of palm oil mill effluent. Advances in Materials Science and Engineering, 4, 1-12. https://doi.org/10.1155/2014/683579.

12. Darajeh, N., Truong, P., Rezania, S., Alizadeh, H., \& Leung, D. W. M. (2019). Effectiveness of vetiver grass versus other plants for phytoremediation of contaminated water. Journal of Environmental Treatment Techniques, 7(3), 485-500.

13. Golubev, I. A. (2011). Handbook of phytoremediation. Handbook of Phytoremediation (1st ed.).

14. Gorito, A. M., Ribeiro, A. R., Almeida, C. M. R., \& Silva, A. M. T. (2017). A review on the application of constructed wetlands for the removal of priority substances and contaminants of emerging concern listed in recently launched EU legislation. Environmental Pollution, 227, 428-443. https://doi. org/10.1016/j.envpol.2017.04.060.

15. Guo, L., \& Cutright, T. J. (2014). Effect of citric acid and rhizosphere bacteria on metal plaque formation and metal accumulation in reeds in synthetic acid mine drainage solution. Ecotoxicology and Environmental Safety, 104(1), 72-78. https://doi. org/10.1016/j.ecoenv.2014.02.019.

16. Instituto da Água. (2009). Critérios para a classificação do estado das massas de água superficiais. Ministério Do Ambiente, Ordenamento Do Território e Do Desenvolvimento Regional (in portuguese).

17. Jampeetong, A., Konnerup, D., Piwpuan, N., \& Brix, H. (2013). Interactive effects of nitrogen form and $\mathrm{pH}$ on growth, morphology, $\mathrm{N}$ uptake and mineral contents of Coix lacryma-jobi L. Aquatic Botany, 111, 144-149. https://doi.org/10.1016/j. aquabot.2013.06.002.

18. Joseph, L., Jun, B. M., Flora, J. R. V., Park, C. M., \& Yoon, Y. (2019). Removal of heavy metals from water sources in the developing world using low-cost materials: A review. Chemosphere, 229, 142-159. https://doi.org/10.1016/j. chemosphere.2019.04.198.

19. Kabata-Pendias, A. (2010). Trace elements in soils and plants: Fourth edition. Trace Elements in Soils and Plants, Fourth Edition, 1-520. https://doi. org/10.1201/b10158.

20. Kadlec, R. H., \& Wallace, S. D. (2009). Treatment Wetlands. Second Edition (2nd ed.).

21. Khellaf, N., \& Zerdaoui, M. (2009). Phytoaccumulation of zinc by the aquatic plant, Lemna gibba L. Bioresource Technology, 100(23), 6137-6140. https://doi.org/10.1016/j.biortech.2009.06.043.

22. Maia, F., Pinto, C., Waerenborgh, J. C., Gonçalves, M. A., Prazeres, C., Carreira, O., \& Sério, S. (2012). Metal partitioning in sediments and mineralogical controls on the acid mine drainage in Ribeira da água Forte (Aljustrel, Iberian Pyrite Belt, Southern Portugal). Applied Geochemistry, 27, 1063-1080. https://doi.org/10.1016/j.apgeochem.2012.02.036.

23. Moore, G. E., Burdick, D. M., Peter, C. R., \& Keirstead, D. R. (2012). Belowground Biomass of Phragmites australis in Coastal Marshes . Northeastern Naturalist, 19(4), 611-626. https://doi. org/10.1656/045.019.0406.

24. Ning, D., Huang, Y., Pan, R., Wang, F., \& Wang, H. (2014). Effect of eco-remediation using planted floating bed system on nutrients and heavy metals in urban river water and sediment: A field study in China. Science of the Total Environment, 485-486(1), 596-603. https://doi.org/10.1016/j. scitotenv.2014.03.103.

25. Nyquist, J., \& Greger, M. (2009). A field study of constructed wetlands for preventing and treating acid mine drainage. Ecological Engineering, 35(5), 630642. https://doi.org/10.1016/j.ecoleng.2008.10.018.

26. Parnian, A., Chorom, M., Jaafarzadeh, N., \& Dinarvand, M. (2016). Use of two aquatic macrophytes for the removal of heavy metals from synthetic medium. Ecohydrology and Hydrobiology, 16(3), 194-200. https://doi.org/10.1016/j. ecohyd.2016.07.001. 
27. Sarwar, N., Imran, M., Shaheen, M. R., Ishaque, W., Kamran, M. A., Matloob, A., ... Hussain, S. (2017). Phytoremediation strategies for soils contaminated with heavy metals: Modifications and future perspectives. Chemosphere, 171, 710-721. https://doi. org/10.1016/j.chemosphere.2016.12.116.

28. Srivastava, J., Kalra, S. J. S., \& Naraian, R. (2014). Environmental perspectives of Phragmites australis (Cav.) Trin. Ex. Steudel. Applied Water Science, 4(3), 193-202. https://doi.org/10.1007/ s13201-013-0142-x

29. Suelee, A. L. (2016). Phytoremediation Potential of Vetiver Grass (Vetiveria zizanioides) for Water Contaminated with Selected Heavy Metal. A project report submitted to the Faculty of Environmental Studies, Universiti Putra Malaysia, in partial fulfilment of the requirement for the degree of Bachelor of Environmental Science and Technology.(06/06/ 2019). https://doi.org/https://doi.org/10.3929/ ethz-b-000238666.

30. Suelee, A. L., Hasan, S. N. M. S., Kusin, F. M., Yusuff, F. M., \& Ibrahim, Z. Z. (2017). Phytoremediation Potential of Vetiver Grass (Vetiveria zizanioides) for Treatment of Metal-Contaminated Water. Water, Air, and Soil Pollution, 228(4), 1-15. https:// doi.org/10.1007/s11270-017-3349-X.

31. Truong, P. N. V., Foong, Y. K., Guthrie, M., \& Hung, Y.-T. (2010). Phytoremediation of Heavy Metal Contaminated Soils and Water Using Vetiver Grass. In Environmental Bioengineering (pp. 233-275). https://doi.org/10.1007/978-1-60327-031-1_8.

32. Vargas, C., Pérez-Esteban, J., Escolástico, C., Masaguer, A., \& Moliner, A. (2016). Phytoremediation of $\mathrm{Cu}$ and $\mathrm{Zn}$ by vetiver grass in mine soils amended with humic acids. Environmental Science and Pollution Research, 23(13), 13521-13530. https://doi. org/10.1007/s11356-016-6430-x.

33. Vymazal, J., \& Březinová, T. (2016). Accumulation of heavy metals in aboveground biomass of Phragmites australis in horizontal flow constructed wetlands for wastewater treatment: A review. Chemical Engineering Journal, 290, 232-242. https://doi. org/10.1016/j.cej.2015.12.108.

34. Walker, C., Tondera, K., \& Lucke, T. (2017). Stormwater treatment evaluation of a Constructed Floating Wetland after two years operation in an urban catchment. Sustainability (Switzerland), 9(10), 1-10. https://doi.org/10.3390/su9101687.

35. Wang, H., \& Jia, Y. (2009). Bioaccumulation of heavy metals by Phragmites australis cultivated in synthesized substrates. Journal of Environmental Sciences, 21(10), 1409-1414. https://doi. org/10.1016/S1001-0742(08)62433-X.

36. Wang, Y., Wen, Y., Li, J. J., He, J., Qin, W. C., Su, L. M., \& Zhao, Y. H. (2014). Investigation on the relationship between bioconcentration factor and distribution coefficient based on class-based compounds: The factors that affect bioconcentration. Environmental Toxicology and Pharmacology, 38(2), 388396. https://doi.org/10.1016/j.etap.2014.07.003.

37. Werner, T. T., Bebbington, A., \& Gregory, G. (2019). Assessing impacts of mining: Recent contributions from GIS and remote sensing. The Extractive Industries and Society, 6(3), 993-1012. https://doi. org/10.1016/j.exis.2019.06.011.

38. Xu, X., \& Mills, G. L. (2018). Do constructed wetlands remove metals or increase metal bioavailability? Journal of Environmental Management, 218, 245-255. https://doi.org/10.1016/j. jenvman.2018.04.014.

39. Zhang, X., Gao, B., \& Xia, H. (2014). Effect of cadmium on growth, photosynthesis, mineral nutrition and metal accumulation of bana grass and vetiver grass. Ecotoxicology and Environmental Safety, 106, 102-108. https://doi.org/10.1016/j. ecoenv.2014.04.025. 